\title{
Co-operative Effect Between $\gamma$-Aminobutyric Acid A Receptors and Central-Type Benzodiazepine Receptors on Amylase Release in Rat Parotid Acinar Cells
}

\author{
Migiwa Okubo ${ }^{1, *}$ and Mitsuru Kawaguchi ${ }^{1}$

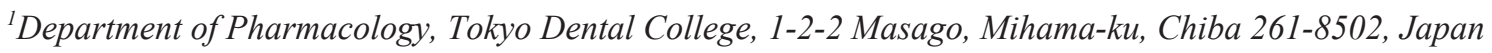

Received September 25, 2009; Accepted December 10, 2009

\begin{abstract}
We investigated the inhibitory role of $\gamma$-aminobutyric acid A $\left(\mathrm{GABA}_{\mathrm{A}}\right)$ receptors on amylase release and the evidence for functional coupling with central-type benzodiazepine receptors in rat parotid acinar cells. Muscimol and GABA decreased isoprenaline-induced amylase release. This effect was blocked by bicuculline, a $\mathrm{GABA}_{\mathrm{A}}$-receptor antagonist, and enhanced by clonazepam, a central-type benzodiazepine-receptor agonist, and diazepam, a central- and peripheral-type benzodiazepine-receptor agonist. Although bicuculline completely blocked the combination effect of $\mathrm{GABA}_{\mathrm{A}}$-receptor agonist and clonazepam, it did not completely block the combination effect with diazepam. These results suggest that protein secretion is suppressively regulated by $\mathrm{GABA}_{\mathrm{A}}$ receptors coupled with central-type benzodiazepine receptors.
\end{abstract}

Keywords: $\gamma$-aminobutyric acid A receptor, parotid gland, amylase release

$\gamma$-Aminobutyric acid A $\left(\mathrm{GABA}_{\mathrm{A}}\right)$ receptors form a complex with the $\mathrm{Cl}^{-}$channel, which regulates $\mathrm{Cl}^{-}$permeability and has binding sites for steroids, barbiturates, and benzodiazepines in the central nervous system (CNS) (1). In addition, $\mathrm{GABA}_{\mathrm{A}}$ receptor has been found in a number of peripheral tissues, including those of the stomach, pancreas, and kidney, where it regulates mucoprotection, glucagon release, and excretory function, respectively $(2-4)$. Previously, our studies showed that inhibitory mechanisms mediated by the GABA receptor and benzodiazepine receptor exist in salivary glands. Our first study demonstrated that GABA and its biosynthetic and metabolic enzyme existed in rat salivary gland (5). Denervation of sympathetic and parasympathetic nerves related to the submandibular glands depressed the immunoreactivities of GABA in those glands (6). These results suggested that the GABAergic system in the glands was closely related to the autonomic nervous system. Moreover, we reported the existence and function of GABA and benzodiazepine receptors in rat salivary gland. Binding sites for the ligands of central-type benzodiazepine receptors (CBRs), peripheral-type ben-

*Corresponding author. okubo@tdc.ac.jp

Published online in J-STAGE on January 30, 2010 (in advance)

doi: 10.1254/jphs.09269SC zodiazepine receptors (PBRs), and $\mathrm{GABA}_{\mathrm{A}}$ receptors were demonstrated to exist in the membrane of rat parotid and submandibular glands using $\left[{ }^{3} \mathrm{H}\right] \mathrm{Ro} 15-1788,\left[{ }^{3} \mathrm{H}\right]$ PK11195, and $\left[{ }^{3} \mathrm{H}\right]$ muscimol, respectively $(7,8)$. Diazepam and clonazepam produced reductions in pilocarpinestimulated salivary secretion using capillaries inserted into the ducts of the parotid glands in the rat in vivo (9) and accelerated ${ }^{36} \mathrm{Cl}^{-}$influx and inhibited its efflux in rat parotid acinar cells in vitro (7). Accumulation of $\mathrm{Cl}^{-}$inhibits movement of water from basal to apical sites in acinar cells. The effect of diazepam on ${ }^{36} \mathrm{Cl}^{-}$influx was further enhanced by muscimol and GABA. Benzodiazepines inhibited carbachol-induced phosphoinositide turnover, which regulates release of calcium from intracellular stores, in rat parotid acinar cells (10). These findings strongly suggest that GABA acts directly on the salivary glands and that GABA receptors contribute to inhibition of salivary secretion. However, whether $\mathrm{GABA}_{\mathrm{A}}$ receptor has a regulatory function in the inhibition of protein secretion such as that of amylase release in salivary gland remains to be established. Previously, we reported that CBR and PBR agonists inhibited amylase release induced by isoprenaline (11). These results suggested the presence of an inhibitory mechanism of protein secretion through $\mathrm{GABA}_{\mathrm{A}}$ receptors in rat salivary gland and that this inhibition was enhanced by 
benzodiazepines. In this study, we investigated the inhibitory effects of $\mathrm{GABA}_{\mathrm{A}}$-receptor agonists on isoprenaline-induced amylase release in rat parotid acinar cells. Moreover, we investigated the relationship between $\mathrm{GABA}_{\mathrm{A}}$ and benzodiazepine receptors in rat parotid acinar cells.

Male Wistar strain rats $(200-250$ g each) were purchased from Japan SLC, Inc. (Hamamatsu). All animals were housed at a constant room temperature $\left(23 \pm 2^{\circ} \mathrm{C}\right)$ with $55 \pm 5 \%$ humidity under a 12-h light/dark cycle (lights on between 6:00 AM and 6:00 PM) and maintained on commercial laboratory chow and tap water for one week prior to initiation of experiments.

Isoprenaline, GABA, muscimol, $N$-[2-hydroxyethyl] piperazine- $N$ '-[2-ethanesulfonic acid] (HEPES), bovine serum albumin, hyaluronidase (type 1-S), and DNA (type 1) were purchased from Sigma (St. Louis, MO, USA). Collagenase (CLSPA) was purchased from Worthington Biochemical (Freehold, NJ, USA). Diazepam, diphenylamine, and 3,5-dinitrosalicylic acid were purchased from Wako (Osaka). Dulbecco's Modified Eagle Medium (DMEM) and Hanks' balanced salt solution (HBSS) were obtained from Gibco BRL (Grand Island, NY, USA). Dimethyl sulfoxide (DMSO) was obtained from Nacalai Tesque (Kyoto). Clonazepam was kindly provided by Dainippon Sumitomo Pharmaceuticals (Osaka). All other reagents used were of the highest grade commercially available. Benzodiazepines were dissolved in DMSO, which had no effect at the concentration used in this study. $\beta$-Adrenoceptor-and GABA-receptor-related agents were dissolved in distilled water. The digestion medium used for acinar cell preparation was DMEM containing $1 \%$ bovine serum albumin, $100 \mathrm{U} / \mathrm{ml}$ collagenase, and $0.15 \mathrm{mg} / \mathrm{ml}$ hyaluronidase. The HBSS-H preparation consisted of HBSS with $1.27 \mathrm{mM} \mathrm{CaCl}_{2}, 0.81 \mathrm{mM}$ $\mathrm{MgSO}_{4}$, and $30 \mathrm{mM}$ HEPES (pH 7.4).

Parotid acinar cells were prepared as in our previous study (11). Minced parotid glands were incubated in the digestion medium for $1 \mathrm{~h}$ at $37^{\circ} \mathrm{C}$ with continuous shaking at 100 cycles/min under an atmosphere of $95 \%$ $\mathrm{O}_{2} / 5 \% \mathrm{CO}_{2}$. After enzyme digestion, the resulting cell aggregates were placed in HBSS-H containing $0.1 \mathrm{mg}$ / $\mathrm{ml}$ bovine serum albumin and further incubated for 20 $\min$ at $37^{\circ} \mathrm{C}$ in the same medium. The acinar cell aggregates obtained were filtered through a $105-\mu \mathrm{m}^{2}$ Nytex nylon screen and suspended in fresh HBSS-H.

Cell suspension was preincubated for $5 \mathrm{~min}$ at $37^{\circ} \mathrm{C}$ with GABA-R- or benzodiazepine receptor-related agents and then further incubated for $30 \mathrm{~min}$ with isoprenaline. After incubation, amylase secretion was terminated by separation of cells and medium with a glass microfiber filter (Whatman GF/C). Medium amylase activity was assayed according to the method of our

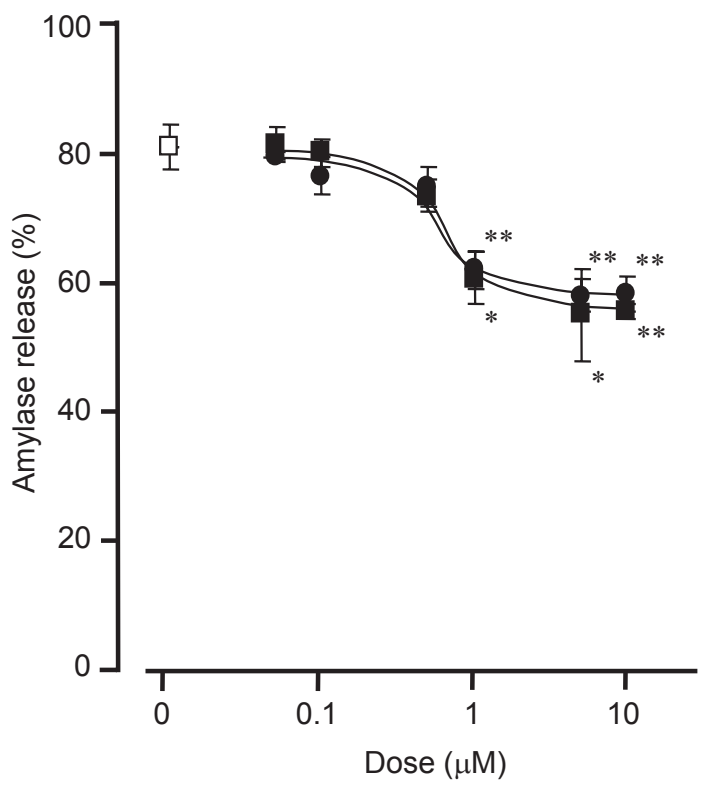

Fig. 1. Effects of GABA-receptor agonists on amylase release induced by isoprenaline in rat parotid cells. Rat parotid acinar cells were preincubated for $5 \mathrm{~min}$ at the indicated concentrations of GABA (closed circle) or muscimol (closed square), respectively, and then further incubated for $30 \mathrm{~min}$ with $1 \mu \mathrm{M}$ isoprenaline. Released amylase was measured and expressed as percentage of total amylase activity in cells. Total amylase activity was $3.27 \pm 0.30 \mathrm{mg}$ maltose $/ \mu \mathrm{g}$ DNA. Data each represent the mean \pm S.E.M. of four to six experiments. ${ }^{*} P<0.05,{ }^{* *} P<0.01$ : significantly different from with isoprenaline alone (open square).

previous study (11), which was the Bernfeld procedure with modifications. Amylase activity was expressed as mg maltose liberated per microgram of DNA in cells. DNA content was assayed by the diphenylamine method (12). Released amylase was expressed as a percentage of total amylase activity in the parotid acinar cells.

The data represent the mean \pm S.E.M. Student's $t$-test or the Dunnett multiple comparison test were used for statistical analysis. The difference in means was considered statistically significant when $P$-values were less than 0.05 .

We investigated the effect of GABA and muscimol as high-affinity $\mathrm{GABA}_{\mathrm{A}}$-receptor agonists on amylase release (Fig. 1). Isoprenaline at $1 \mu \mathrm{M}$ significantly increased amylase release, with release occupying $80.8 \%$ of total amylase activity in the cells. GABA and muscimol significantly decreased isoprenaline-induced amylase release in a concentration-dependent manner. The maximum decrease was obtained with $0.5 \mu \mathrm{M}$ GABA or muscimol, with isoprenaline-induced amylase release being decreased to $57.6 \%$ or $54.9 \%$ of total amylase activity, respectively. The concentration of GABA or muscimol required to induce an inhibitory effect was similar to that required to induce ${ }^{36} \mathrm{Cl}^{-}$influx (7). Bicu- 
Table 1. Effects of $\mathrm{GABA}_{\mathrm{A}}$-receptor antagonist on inhibition of isoprenaline-induced amylase release by $\mathrm{GABA}_{\mathrm{A}}$-receptor and benzodiazepine-receptor agonist in rat parotid cells

\begin{tabular}{lcr}
\hline & \multicolumn{2}{c}{ Amylase release ratio } \\
\cline { 2 - 3 } & without BCC & with BCC \\
\hline ISP & 100 & \\
+ GABA & $83.0 \pm 3.3$ & $98.2 \pm 2.1^{* *}$ \\
+ DZP & $54.7 \pm 3.0$ & $77.3 \pm 4.2^{* *}$ \\
+ CZP & $63.4 \pm 2.4$ & $96.5 \pm 2.8^{* *}$ \\
+ MUS & $81.8 \pm 1.1$ & $101.2 \pm 3.0^{* *}$ \\
+ DZP & $52.0 \pm 2.2$ & $79.8 \pm 4.0^{* *}$ \\
+ CZP & $59.5 \pm 1.1$ & $95.6 \pm 3.3^{* *}$ \\
\hline
\end{tabular}

GABA at $1 \mu \mathrm{M}$ or $0.5 \mu \mathrm{M}$ muscimol (MUS) were preincubated for 5 min with $1 \mu \mathrm{M}$ diazepam (DZP) or $1 \mu \mathrm{M}$ clonazepam (CZP) with/ without $10 \mu \mathrm{M}$ bicuculline (BCC), and further incubated for $30 \mathrm{~min}$ with $1 \mu \mathrm{M}$ isoprenaline (ISP). Released amylase was measured and expressed as percentage of amylase release induced by isoprenaline alone. Data represent mean \pm S.E.M. of five experiments. $* * P<0.01$ : Significantly different from without bicuculline, respectively.

culline, a selective $\mathrm{GABA}_{\mathrm{A}}$-receptor antagonist, completely blocked inhibition of isoprenaline-induced amylase release by GABA or muscimol (Table 1). These results strongly suggest the existence of $\mathrm{GABA}_{\mathrm{A}}$ receptors in salivary gland and their involvement in regulation of amylase release.

Clonazepam, as a CBR agonist and diazepam, as both a CBR and PBR agonist, further enhanced the inhibitory effects of GABA and muscimol on isoprenaline-induced amylase release in a dose-dependent manner (Fig. 2). Amylase release induced by isoprenaline alone was reduced to $83.0 \%$ by $0.5 \mu \mathrm{M}$ GABA (Fig. $2 \mathrm{a}$ ). Clonazepam at $1 \mu \mathrm{M}$ and diazepam at $1 \mu \mathrm{M}$ further inhibited GABAinduced decrease in amylase release to $54.7 \%$ and $63.4 \%$ of levels measured after incubation with isoprenaline alone, respectively. Similarly, amylase release induced by isoprenaline alone was reduced to $81.8 \%$ by $0.5 \mu \mathrm{M}$ muscimol (Fig. 2b). Clonazepam at $1 \mu \mathrm{M}$ and diazepam at $1 \mu \mathrm{M}$ further inhibited muscimol-induced decrease in amylase release to $52.0 \%$ and $59.5 \%$ of levels measured after incubation with isoprenaline alone, respectively. The enhancement effect of diazepam was approximately $10 \%$ stronger than that of clonazepam. This coupling effect between GABA agonists and benzodiazepine agonists was blocked by bicuculline (Table 1). The coupling effect of GABA or muscimol and clonazepam, in particular, was completely blocked by bicuculline. These results suggest that $\mathrm{CBRs}$ co-operate with $\mathrm{GABA}_{\mathrm{A}}$ receptors in the regulation of amylase release in rat parotid acinar cells. This agrees with the findings of earlier studies that demonstrated that CBRs allosterically regulated $\mathrm{GABA}_{\mathrm{A}}$
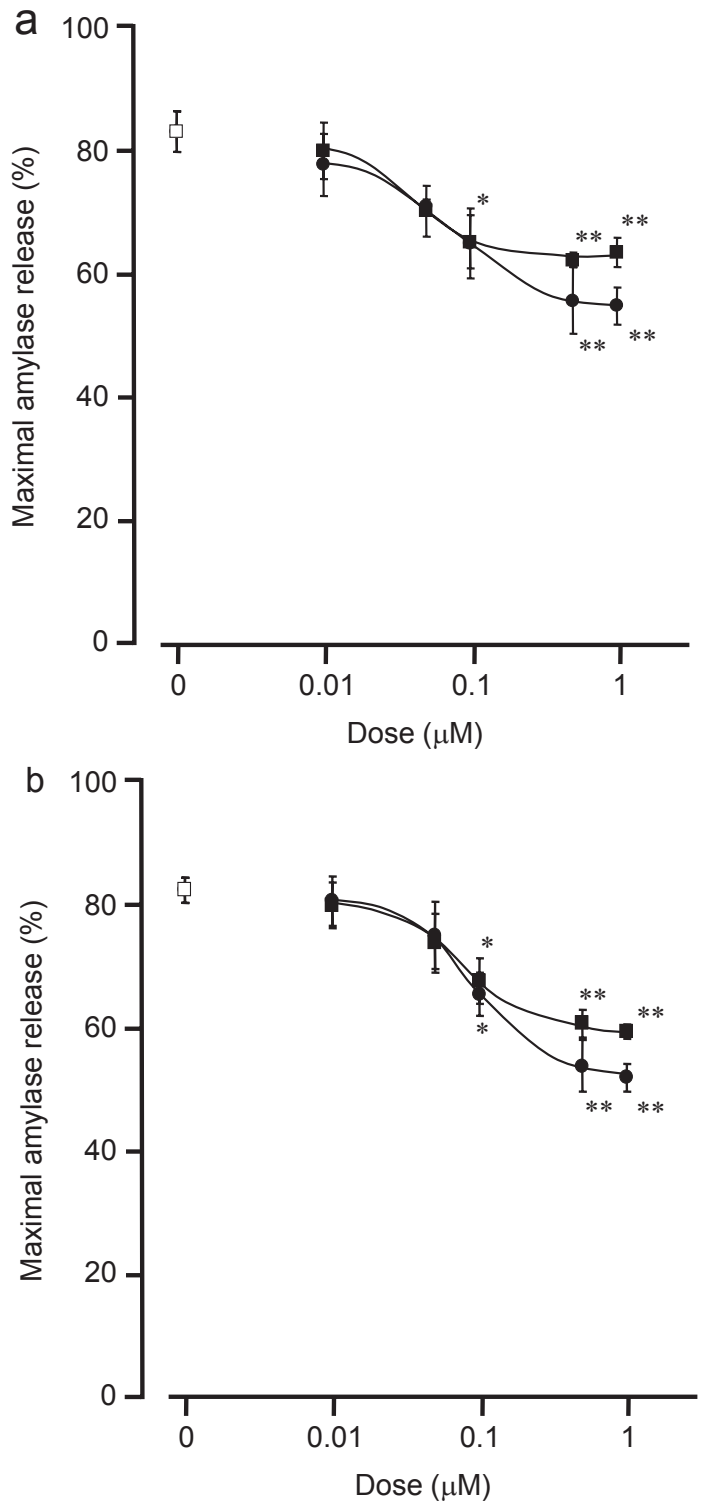

Fig. 2. Effects of benzodiazepine-receptor agonist on inhibition of isoprenaline-induced amylase release by GABA (a) and muscimol (b) in rat parotid cells. a) Rat parotid acinar cells were preincubated for 5 min with $0.5 \mu \mathrm{M}$ GABA and the indicated concentrations of diazepam (circle) or clonazepam (square) and further incubated for $30 \mathrm{~min}$ with $1 \mu \mathrm{M}$ isoprenaline. b) Rat parotid acinar cells were preincubated for 5 min with $0.5 \mu \mathrm{M}$ muscimol and the indicated concentrations of diazepam (circle) or clonazepam (square) and further incubated for 30 min with $1 \mu \mathrm{M}$ isoprenaline. Released amylase was measured and expressed as percentage of amylase release induced by isoprenaline alone. Data each represent the mean \pm S.E.M. of three to four experiments. ${ }^{*} P<0.05,{ }^{* *} P<0.01$ : Significantly different from GABA or muscimol alone.

receptors in the CNS $(1,13)$. In contrast, bicuculline did not completely block the coupling effect of GABA or muscimol and diazepam. Moreover, clonazepam and diazepam had different abilities to enhance GABA-in- 
duced inhibition of amylase release (Fig. 2). These results raise the possibility that the remaining effect of diazepam was obtained through the PBR. This is supported by the results of our earlier study demonstrating that Ro5-4864, a PBR agonist, dose-dependently decreased isoprenalineinduced amylase release and the inhibitory effect was blocked by PK11195, a PBR antagonist (11).

The mechanism by which isoprenaline-induced amylase release is inhibited by activation of $\mathrm{GABA}_{\mathrm{A}}$ receptors remains to be established. Isoprenaline stimulates $\beta$-adrenoceptors and increases intracellular cyclic AMP through GTP-dependent regulatory proteins (G protein) and adenylate cyclase. Cyclic AMP activated protein kinase A and exocytosis of protein from luminal sites (14). These intracellular signaling factors may be involved in change in cytosolic $\mathrm{Cl}^{-}$concentration (7), cytosolic $\mathrm{Ca}^{2+}$ concentration (10), and cytosolic $\mathrm{pH}$ regulation by GABA-induced $\mathrm{Cl}^{-}$influx. However, further study is necessary to elucidate these mechanisms.

In conclusion, the results of the present study suggest that protein secretion is suppressively regulated by $\mathrm{GABA}_{\mathrm{A}}$ receptors coupled with CBRs. In addition, regulation of PBRs on protein secretion was independent of that of $\mathrm{GABA}_{\mathrm{A}}$ receptors.

\section{Acknowledgments}

We are grateful to Dainippon Sumitomo Pharmaceuticals for their generous gift of clonazepam. This work was supported by Grant 13771102 from the Science Research Fund of the Ministry of Education, Culture, Sports, Science, and Technolosy of Japan. The authors would like to thank Associate Professor Jeremy Williams, Tokyo Dental College, for his assistance with the English of the manuscript.

\section{References}

1 Sieghart W. GABA receptors: ligand-gated $\mathrm{Cl}^{-}$ion channels modulated by multiple drug-binding sites. Trends Pharmacol Sci.
1992;13:446-50.

2 Erdö SL, Ezer E, Matuz J, Wolff JR, Amenta F. GABA A $_{\text {receptors }}$ in the rat stomach may mediate mucoprotective effects. Eur J Pharmacol. 1989;165:79-86.

3 Xu E, Kumar M, Zhang Y, Ju W, Obata T, Zhang N, et al. Intraislet insulin suppresses glucagon release via GABA-GABAA receptor system. Cell Metab. 2006;3:47-58.

4 Monasterolo LA, Trumper L, Elías MM. Effects of gammaaminobutyric acid agonists on the isolated perfused rat kidney. $\mathrm{J}$ Pharmacol Exp Ther. 1996;279:602-607.

5 Sawaki K, Ouchi K, Sato T, Kawaguchi M. Existence of gammaaminobutyric acid and its biosynthetic and metabolic enzymes in rat salivary glands. Jpn J Pharmacol. 1995;67:359-363

6 Kosuge Y, Kawaguchi M, Sawaki K, Okubo M, Shinomiya T, Sakai T. Immunohistochemical study on GABAergic system in salivary glands. Eur J Pharmacol. 2009;610:18-22.

7 Kawaguchi M, Yamagishi H. Coupling of benzodiazepine and GABA(A) receptors in the salivary glands is a factor of drug-induced xerostomia. Int Acad Biomed Drug Res. 1996;11: 291-296.

8 Yamagishi H, Kawaguchi M. Characterization of central- and peripheral-type benzodiazepine receptors in rat salivary glands. Biochem Pharmacol. 1998;55:209-214.

9 Kawaguchi M, Ouchi K, Ohse S, Baba Y. In vivo and in vitro studies on receptive mechanisms for benzodiazepines in rat parotid gland. Dent Jpn. 1995;32:38-40.

10 Kujirai M, Sawaki K, Kawaguchi M. Inhibitory effect of diazepam on muscarinic receptor-stimulated inositol 1,4,5-trisphosphate production in rat parotid acinar cells. Br J Pharmacol. 2002; 137:945-952.

11 Okubo M, Kawaguchi M. Inhibitory regulation of amylase release in rat parotid acinar cells by benzodiazepine receptors. Eur J Pharmacol. 1998;359:243-249.

12 Richards GM. Modifications of the diphenylamine reaction giving increased sensitivity and simplicity in the estimation of DNA. Anal Biochem. 1974;57:369-376.

13 Tamaki R, Oshikawa M, Shinomiya T, Andoh H, Kawaguchi M, Hashimoto A, et al. Chronic administration of methamphetamine increases the mRNA expression of diazepam binding inhibitor in rat brain. Tokai J Exp Clin Med. 2008;33:46-50.

14 Baum BJ. Neurotransmitter control of secretion. J Dent Res 1987;66:628-632 